\title{
Identification and assessment of elevated exposure to natural radiation in Balkan region (Serbia)
}

Z.S. Žunić ${ }^{1}$, I.V. Yarmoshenko ${ }^{2}$, N. Veselinović ${ }^{1}$, M.V. Zhukovsky ${ }^{2}$, P. Ujić ${ }^{1}$, I. Čeliković ${ }^{1}$, J.P. Mc Laughlin ${ }^{3}$, S.E. Simopoulos ${ }^{4}$, A. Birovljev ${ }^{5}$, K. Fujimoto ${ }^{6}$, J. Paridaens ${ }^{7}$, F. Trotti ${ }^{8}$, S. Tokonami ${ }^{6}$, P. Olko ${ }^{12}$, K. Kozak ${ }^{12}$, F. Bochicchio ${ }^{10}$, R. Ramola ${ }^{13}$, J.W. Mietelski ${ }^{12}$, B. Jakupi ${ }^{9}$, G. Milić ${ }^{9}$, G. Ciotoli ${ }^{11}$, K. Kelleher ${ }^{3}$, M. Budzanowski ${ }^{12}$, S.K. Sahoo ${ }^{6}$, H. Vanmarcke ${ }^{7}$ and M.P.R. Waligorski ${ }^{12}$

1 Institute of Nuclear Sciences "Vinča", Belgrade, Serbia

${ }^{2}$ Institute of Industrial Ecology, Ural Branch of Russian Academy of Sciences, Ekaterinburg, Russia

${ }^{3}$ Radiological Protection Institute of Ireland, Dublin, Ireland

${ }^{4}$ Nuclear Engineering Department, National Technical University of Athens, Athens, Greece ${ }^{5}$ Radonlab Ltd., Oslo, Norway

${ }^{6}$ National Institute of Radiological Sciences, Chiba, Anagawa, Inage-ku, Japan ${ }^{7}$ SCK-CEN, Mol, Belgium

${ }^{8}$ Venetian Reference Laboratory for Environmental Radioactivity, CRR-ARPAV, Verona CRR-Policlinico B. Roma, Verona, Italy

${ }^{9}$ Physics Department, Faculty of Natural Sciences and Mathematics, Priština, Serbia

${ }^{10}$ Italian National Institute of Health, Rome, Italy

${ }^{11}$ Department of Earth Sciences, University of Rome "La Sapienza", Rome, Italy

${ }^{12}$ The Henryk Niewodniczański Institute of Nuclear Physics PAN, Krakow, Poland

${ }^{13}$ Department of Physics, H.N.B. Garhwal University, Garhwal, India

\begin{abstract}
The paper deals with a specific aspect of a general survey, that is being carried out during last ten years in several regions of Serbia (former Yugoslavia, former Serbia and Montenegro) to assess population exposure to natural radioactivity based on geochemical and integrative pattern research approach. The originality regarding this work is related to the facts such as follows: the first identification and assessment of high areas of natural radiation in Serbia which provides insight into its regional characteristics, the interpretation of the results in terms of geological aspects, building types and human habits, the first introduction and field applicability of both (surface and volume trap) retro techniques in Serbia and assessment of doses and risks to the population in investigated high natural radiation rural communities.
\end{abstract}

\section{INTRODUCTION}

Although radon, being the most important natural source of population radiation exposure, has been well explored issue, for Serbia and most of the countries at Balkan region, there is no systematic data on the levels of radon exposure in its dwellings. As reliable assessment of population exposure to natural radiation environment requires proper structured program of radiation measurements and due to the fact that the program should be based on thorough analysis of background information on geology of local territory, its building construction traditions and its population lifestyle, since 1997 several hundred houses in rural communities of South Serbia and Kosovo, Southeast and West Serbia, in Republic Srpska (Bosnia and Herzegovina) and in Montenegro has been investigated. From the geological point of view each region has its own specific peculiarity and some of are associated with high level of 
natural radiation: Niška Banja, Southeast Serbia - presence of radium rich travertine; Gornja Stubla, Kosovo - combined uranium-thorium anomalous zone; Kalna, Southeast Serbia - former uranium mining area in granite massive. Protocols of the field investigations to assess population exposure in these regions included indoor and outdoor radon measurements, air kerma measurements as well as soil and water radioactivity measurements. Most attention was paid to indoor radon exposure. Various advanced techniques of indoor radon measurements were applied involving both surface and volume retrospective approaches simultaneously at the same indoor spaces. Indoor thoron gas concentrations were investigated as well. Performed analysis of radon surveys data included study of seasonal and long-term variation, comparison of contemporary and retrospective measurements, analysis of factor affecting indoor radon levels, dose and risk assessment.

\section{MATERIAL AND METHODS}

\subsection{Contemporary radon and thoron measurements}

Several differently designed chambers for the CR-39 and polycarbonate detectors were used such as: SSI/NRPB detectors, the CR-39 detectors enclosed in small cylindrical $(5 \mathrm{~cm}$ height, $3 \mathrm{~cm}$ diameter) diffusion chamber, passive discriminative Cr-39 Radopot and Raduet detectors [1], passive discriminative polycarbonate UFO detectors [2, 3]. Exposure periods were generally of about 3 months covering one season. Annual averages were obtained using either results of all the seasonal measurements, if available, or results of some periods corrected with seasonal factors [4]. Polycarbonate films were etched electrochemically [3].

\subsection{Retrospective Assessment of Radon Exposure (RARE) techniques}

In recent years two methods of retrospective radon assessment have been developed, both based on measuring the activity of the long-lived radon daughter ${ }^{210} \mathrm{~Pb}$ by means of its alpha emitting daughter ${ }^{210} \mathrm{Po}$. The ${ }^{210} \mathrm{~Pb}$ has been accumulated over many years on the surface of solid media (mostly glass), known as surface traps (ST) [5-8], or in the bulk of porous media (mostly furniture filling sponges), known as volume traps (VT) [9]. Activity of ${ }^{210} \mathrm{Po}$ can be related to the long-term average indoor radon concentration. While the ST technique is based on solid state detectors (CR-39 and LR115), the VT technique uses radiochemical procedures and alpha spectrometry. Both retro techniques, i.e., ST and VT were applied successfully in three rural communities: Kalna, Gornja Stubla and Niška Banja, i.e., have been tested for a large scale in surveys and the same indoor spaces data were available from surface traps, volume traps and contemporary radon measurements $[10,11]$ as well as a study by Paridaens et al. [12].

In the ST technique, glass usually found in photograph and picture frames is used, because it is often easy to date it. The measurement material for the VT technique is typically a $100 \mathrm{~cm}^{3}$ polyester foam sample taken from mattresses or cushions used in a dwelling. One of the major disadvantages is that the technique is destructive and so occupants are sometimes reluctant to supply samples for the measurement. In principle the measured longlived radon progeny should be directly proportional to the long term average radon in the house and unlike the ST technique is independent of aerosol conditions in room air.

\subsection{Placement and retrieval of detectors in dwellings}

The fieldwork has been carried out by the members of the Institute of Nuclear Sciences "Vinča" (Belgrade). A detailed questionnaire was completed for each room of interest that recorded a number of other relevant factors relating to indoor radon. These factors were then used in conjunction with the modified Jacobi room model [13] in order to better estimate the average radon concentration. The ST 
monitors were left in-situ for a period of approximately 3 months before being removed and sent to Ireland (University College Dublin) for analysis. The VT samples were sent to Belgium (SCK.CEN, Mol) for analysis.

\subsection{Long-term changes of indoor radon concentration}

When comparing the retrospective and contemporary measurements results it is necessary to take into account the long-term indoor radon changes [14]. Changes and transformations of construction components (such as basement, construction joints, insulation, interface gaps etc.), building underlying soil physical condition and occupant living habits may in the course of time result in systematic changes of the radon entry. Analysis of retrospective indoor radon concentrations estimated over different ages of volume or surface traps can be somehow biased under condition of substantial long-term change of indoor radon. For example retrospective estimates of indoor radon concentration in the same space using two separate objects of different age may be found to be inconsistent. On the other hand the difference between radon concentrations determined by retrospective and contemporary technique can be rather explained by long-term changes than by strong measurements error. Thus the consideration of such processes allows meaningful comparison of contemporary and retrospective data as well as investigation of its pattern using these data. By the results of radon entry modeling the long-term character of the indoor radon variation is close to linear [14] though the year-by-year variation could be random. In particular, to describe monotonous long-term changes a coefficient $\mathrm{k}$ equal to the ratio of the annual radon concentration of two consecutive years has been introduced. Using this coefficient, retrospective indoor radon concentration CR (average of annual radon concentrations within a period equal to the age, A, of the "trap") is connected with contemporary indoor radon concentration [14].

\section{EXPOSURE, DOSE AND RISK ESTIMATION}

\subsection{Health implications of long term radon exposure}

As described above radon concentrations were measured in many dwellings in the investigated areas. In many cases the concentrations were well above what are considered as unacceptably high levels from a health perspective for human exposure. For example in many countries there are ranges of radon action or reference levels above which it is recommended that remedial action should take place to reduce high radon exposures. These action or reference levels differ from country to country but are generally in the range 200 to $600 \mathrm{~Bq} / \mathrm{m}^{3}$ [15]. Therefore it is necessary to estimate the lung cancer risk of the population in these communities in Serbia where their indoor radon levels exceeded the action or reference levels.

Radon is one of a very small number of substances which have been confirmed to be human carcinogens based on human studies. And radon is a Group 1 and Group A carcinogen, according to the classifications used by the World Health Organisation (WHO/IARC) and by the US Environmental Protection Agency [16], respectively. The principal adverse health effect arising from the inhalation of radon and mainly its decay products is lung cancer. From a health perspective the most significant daughter products are ${ }^{218} \mathrm{Po},{ }^{216} \mathrm{Po},{ }^{214} \mathrm{Po},{ }^{212} \mathrm{Po}$. These elements, unlike radon, shortly after their formation attach themselves to aerosol particles; a small fraction of them remain in unattached form, depending on aerosol size and concentration and ventilation rate [17]. For the risk assessment of general population radon exposure (as distinct from occupational exposure) two different approaches can be used to estimate the lung cancer risk arising from exposure to radon decay products.

The dosimetric approach, in which the radiation doses to lung tissues is estimated and the associated risk is evaluated using currently accepted dose/risk factors for ionising radiations and the residential epidemiology approach, in which case-control studies of the general population are used to derive risk factors. 
In the following sections the risk to the exposed populations in the investigated areas of Serbia will be estimated and compared using both approaches.

\subsection{The dosimetric approach}

Here the dose to the lung is estimated using models of lung deposition of radon progeny and dosimetry. A number of such models exist and while they are similar in many regards they differ in a number of key assumptions such as: the identification and location of the sensitive cells in lung, the weighting factor for alpha radiation. In addition at the level of the individual person physiological factors as lung morphometry, breathing rate, smoking habits, lung clearance rate, solubility of radon progeny in lung etc would need to be taken into account. It is decided to use for estimating the doses to the general population, which includes both smokers and non-smokers, a single value of $0.065 \mathrm{mSv} \mathrm{Bq}^{-1} \mathrm{~m}^{3} \mathrm{y}^{-1}$ for the dose/exposure conversion factor for estimating the doses to the general population, which includes both smokers and non-smokers. This value is derived from the work of Marsh, Birchall and Davis [18] based on the not unreasonable assumption of a $40 \%$ prevalence of smoking in the general population of Serbia. Other dose/exposure conversion factors are available in the current literature but are not significantly different from this value. It should be noted that the dose referred to is the "effective dose". For purposes of estimating the dose and risk to the general population in the investigated areas tissue weighting factor of 0.12 for lung and use fatal cancer risk is taken into account and for estimating the lifetime risk, lifetime of 70 years is considered. Estimated life time risk for radon induced lung cancer in 3 rural communities in Serbia: Kalna, Gornja Stubla, Niška Banja are estimated and presented in the Table 1.

Table 1. Estimation of lifitime risk for lung cancer by dosimetric and epidemiological approach in 3 rural communities in Serbia.

\begin{tabular}{|l|c|c|c|c|c|c|}
\hline & & \multirow{2}{*}{$\begin{array}{c}\text { Dosimetric } \\
\text { approach }\end{array}$} & $\begin{array}{c}\text { Epidemiological } \\
\text { approach }\end{array}$ & \multicolumn{2}{|c|}{$\begin{array}{c}\text { Epidemiological approach } \\
\text { approach Fatal lung cancer }\end{array}$} \\
\cline { 4 - 7 } $\begin{array}{l}\text { Rural } \\
\text { communities }\end{array}$ & $\begin{array}{c}\text { C }\left({ }^{222} \mathrm{Rn}\right) \\
\mathrm{Bq} \mathrm{m}^{-3}\end{array}$ & $\begin{array}{c}\text { Lifetime risk for } \\
\text { lung cancer }\end{array}$ & $\begin{array}{c}\text { compared to non } \\
\text { Rn environment }\end{array}$ & $\begin{array}{c}\text { For non } \\
\text { smokers }\end{array}$ & For smokers & $\begin{array}{c}\text { popula- } \\
\text { tion }\end{array}$ \\
\hline Kalna & 188 & 1.9 & $15 \%$ & $0.48 \%$ & $11.63 \%$ & $4.7 \%$ \\
\hline Gornja Stubla & 447 & 4.6 & $35 \%$ & $0.55 \%$ & $13.6 \%$ & $5.5 \%$ \\
Niška Banja & 1167 & 12 & $93 \%$ & $0.8 \%$ & $19.5 \%$ & 8.4 \\
\hline
\end{tabular}

It is fully realized that a number of assumptions are made to derive these estimations. However, as they are not unreasonable these estimates may be taken as reasonable values at least for the purpose of comparing the radon risk between these three areas. It cannot be overemphasized that such estimates are not meant to apply at the level of an individual person but may be useful to decision makers and health authorities to develop policies and strategies for reducing future radon exposures and associated risks in these areas, since ICRP as well as IAEA recommend some action levels for radon to reduce radon exposure in each country.

\subsection{The epidemiological approach}

In past decades epidemiological studies on the health effects of radon exposure have been made for underground miner cohorts (mainly on uranium and other hard rock miners). The results of these cohort studies have been extended to use for the estimation of risks to the general population exposed in their homes. In recent years, however, a number of major epidemiological case-control studies on the public in their homes (radon residential studies) have taken place which gives more direct epidemiological information on the risk to the public. Recently the detailed results of a collaborative analysis on individual data of 7148 persons with lung cancer and 14208 persons without lung cancer 
from 13 epidemiological studies in Europe has been published [19]. This is the largest and most comprehensive study of this type published in the literature to date. The excess relative risk of lung cancer per $100 \mathrm{Bqm}^{-3}$ was estimated to be $0.08(95 \% \mathrm{CI} 0.03-0.16 ; \mathrm{p}=0.0007)$ after adjusting confounding factors. It was not found that the excess relative risk varied with age, sex or smoking habits. Obviously the absolute risk of lung cancer for non-smokers is much lower than for smokers but the excess relative risk was essentially the same for both groups. Assigning a risk factor to be unity $(=1)$ for non-smokers at zero radon then for smokers the analysis of this study yielded a relative risk value of 25.8 at zero radon. Then using the excess relative risk factor of 0.08 (given above) we can estimate that the relative risk to a non-smoker at $100 \mathrm{~Bq} / \mathrm{m}^{3}$ (for example) increases from 1 to $1 \cdot 1.08=1.08$ while for a smoker it increases from 25.8 to $25.8 \cdot 1.08=27.86$. This relative risk estimation from [19] will now be applied to the populations in the three investigated areas in Serbia. In the study of Darby et al. [19], the percentages of actual fatal lung cancer for both non-smokers and smokers are estimated $0.41 \%(=0.0041)$ and $10.11 \%(=0.1011)$ by age 75 years, respectively. On the basis of these values, increased risk compared to non radon environment and to fatal lung cancer in the investigated areas: Kalna, Gornja Stubla, Niška Banja are presented in the Table 1.

\subsection{Comment}

While the risk estimates using the dosimetric and epidemiological approaches are not in agreement (not can we reasonably expect them to be so) they both indicate that the elevated radon in these communities may represent a significant health risk. It must also be stated and it cannot be overemphasized enough that all the above estimates (both using the dosimetric and epidemiological approaches) are based on many simplifying assumptions. Disregarding anecdotal non-scientific comment on lung cancer incidence in these communities the actual values of lung cancer incidence in these communities as a function of age, sex, radon exposure, smoking habits etc., in these communities are not presently known. This may become in the future a topic of epidemiological study. Nevertheless the risk estimates using either approach suggest that the high radon levels in these three communities (and in particular in Niška Banja) may represent a significant public health risk. From a positive perspective it is worth noting that building construction regulations now exist in a number of European countries which for new buildings make it possible to construct dwellings with low indoor radon levels even in areas where the rocks and soils contain elevated radon levels.

\section{RESULTS AND CONCLUSIONS}

The indoor radon levels in Serbia and some part of Balkan region for dwellings in different rural communities follow lognormal distribution $(\mathrm{GSD}=1.8 \div 3.2$ ), strongly depend on the type of underlying rock and average radon levels range between $45 \mathrm{Bqm}^{-3}$ for limestone (Montenegro) and $1560 \mathrm{Bqm}^{-3}$ for travertine (Niška Banja) [20-23].

Highest obtained average indoor radon concentrations were about $1200 \mathrm{Bqm}^{-3}$ in Niška Banja, $500 \mathrm{Bqm}^{-3}$ in Gornja Stubla and $200 \mathrm{Bqm}^{-3}$ in Kalna. As estimated by parameters of lognormal distribution part of houses with indoor radon concentration above $600 \mathrm{Bqm}^{-3}$ were $46 \%$ in Niška Banja, $23 \%$ in Gornja Stubla and $1.4 \%$ in Kalna.

In Balkan region there is the tendency to the increasing of the indoor radon concentrations during the ageing of the dwellings, but the different techniques or retrospective radon measurements gives the different values for expected value of decade increasing coefficient (VT retro technique gives higher value of decade increasing coefficient than ST technique) [10, 11, 14, 23-25]. It can be explained by the significant influence of aerosol concentration on the assessment of retrospective value of radon concentration by surface trap technique.

The season variations of indoor radon concentrations in Balkan region can be described by linear regression model relating summer and winter indoor radon concentrations with the typical value of 
slope factor $B \sim 0.2 \div 0.6$ and intercept parameter $\mathrm{A}=3 \div 40 \mathrm{Bqm}^{-3}[21,22]$. It is proved that there is negative dependency between the number of smokers in the dwelling and the average radon concentration and this fact should be taken into account during the epidemiological studies [14]. In some regions of Balkan (Gornja Stubla) the indoor thoron levels are significant and should be taken into account during both radon measurements and radiation dose and risk assessment [20, 22, 26, 27].

\section{Acknowledgement}

The authors wish to acknowledge the Ministry of Science of the Republic of Serbia for support under the project P-141019B and to generous cooperation of the people of the communities of Kalna, Gornja Stubla, Niška Banja and Han PijesakKalna, Gornja Stubla, Niška Banja and Han Pijesak.

\section{References}

[1] Tokonami S., Takahashi H., Kobayashi Y., Zhuo W. and Hulber E., Rev. Sci. Instrum. 76 (2005) 113505.

[2] Doi M., Fujimoto K., Kobayashi S. and Yonehara H., Health Phys. 66 (1994) 1, 43-49.

[3] Žunić Z.S., Ujić P., Čeliković I. and Fujimoto K., Nucl. Technol. Radiat. Prot. 18 (2003) 2, 57-60.

[4] Žunić Z.S., Yarmoshenko I.V., Kelleher K., Paridaens J., Mc Laughlin J.P., Čeliković I., Ujić P., Onischenko A.D., Jovanović S., Demajo A., Birovljev A. and Bochicchio F., Sci. Total Environ. 387 (2007) 269-275.

[5] Samuelsson C. Nat. 334 (1988) 338-40.

[6] Samuelsson C, Johansson L. and Wolff M. Radiat. Prot. Dosim. 45 (1992) 73-75.

[7] Lively R.S. and Steck D.J., Health Phys. 64 (1993) 485-490.

[8] Falk R., Mellander H., Nyblom L. and Ostergren I,. Environ. Inst. 22 (1996) S857-S861.

[9] Oberstedt S. and Vanmarcke H., Health Phys. 70 (1996) 223-226.

[10] Žunić Z.S., McLaughlin J.P., Walsh C. and Benderac R., Radiat. Meas. 31 (1999) 343-346

[11] Paridaens J., Vanmarcke H., Jacobs K. and Zunic Z. Appl. Radiat. Isot. 53 (2000) 1-2, 361-364

[12] Paridaens J., Vanmarcke H., Zunic Z. and McLaughlin J.P., Sci. Total Environ. 272 (2001) 295302.

[13] Jacobi W., Health Phys. 22 (1972) 441

[14] Yarmoshenko I.V., Zunic Z.S., McLaughlin J.P., Paridaens J., Kirdin I.A. and Kelleher K., Radioact. Environ. 7 (2005) 726-730

[15] ICRP-65. Protection Against Radon-222 at Home and at Work (Pergamon Press 1994) Ann ICRP 23

[16] U.S. EPA, 1987. U.S. Environmental Protection Agency. Radon Reference Manual. Office of Radiation Programs EPA 520/1-87-20 (Washington, DC., 1987)

[17] Nazaroff W.W., Moed B.A. and Sextro R.G. Soil as a source of indoor radon: generation, migration, and entry. in: Radon and its decay products in indoor air, eds. Nazaro. W. W and Nero A. V., (John Wiley \& Sons, 1988) pp. 57-112.

[18] Marsh J.W., Birchall A. and Davis K., Radioact. Environ. 7 (2005) 290-298.

[19] Darby S., Hill D., Deo H., Auvinen A., Barros-Dios J.M., Baysson H., Bochicchio F., Falk R., Farchi S., Figueiras A., Hakama M., Heid I., Hunter N., Kreienbrock L., Kreuzer M., Lagarde F., Mäkeläinen I., Muirhead C., Oberaigner W., Pershagen G., Ruosteenoja E., Rosario A.S., Tirmarche M., Tomásek L., Whitley E., Wichmann H.E. and Doll R.S., Scand. J. Work, Environ. and Health 32 (2006) Supple 1, 1-83.

[20] Žunić Z.S., Mc Laughlin J.P., Yamoshenko I.V., Pavlyuk A.V. and Kirdin I., Field work studies on natural indoor radiation population exposures in Yugoslavia - new results The Proc. of $3^{\text {rd }}$ International Nuclear Society Conference, Belgrade, Yugoslavia (2000). 801-806. 
[21] Žunić Z.S., Yarmoshenko I.V., Zhukovsky M., Mc Laughlin J.P. and Fujimoto K., Statistical Analysis of Radon Survey Results Proc. of the $5^{\text {th }}$ Intern. Conf. High Levels of Natural Radiation and Radon Areas. Munich, 4-7 Sept. 2000. (BFS, 2002) vol. 2. pp. 197-200.

[22] Žunić Z.S., Fujimoto K. and Yarmoshenko I.V., Int. Congr. Ser. 1276 (2005) 141-144.

[23] Žunic Z.S., Yarmoshenko I.V., Birovljev A., Bochicchio F., Quarto M., Obryk B., Paszkowski M., Čeliković I., Demajo A., Ujić P., Budzanowski M., Olko P., McLaughlin J.P. and Waligorski M.P.R., J. Environ. Radioact. 92 (2007) No. 3. 165-174.

[24] Zunic Z.S., McLaughlin J.P., Walsh C., Birovljev A., Simopoulos S.E., Jakupi B., Gordanic V., Demajo M., Trotti F., Falk R., Vanmarcke H., Paridaens J. and Fujimoto K., Sci. Total Environ. 272 (2001) Issues 1-3, 253-259.

[25] Paridaens J., Zunic Z.S., Trotti F., McLaughlin J.P. and Vanmarcke H., Int. Congr. Ser. 1225 (2002) 87-93.

[26] Žunić Z.S., Kobal I., Vaupotič J., Kozak K., Mazur J., Birovljev A., Janik M., Čeliković I., Ujić P., Demajo A., Krstić G., Jakupi B., Quarto M. and Bochicchio F., J. Environ. Radioact. 89 (2006) 3, 249-260.

[27] Žunić Z.S., Fujimoto K., Yarmoshenko I.V., Birovljev A., Čeliković I., Ujić P., Simopoulos S.E., Olko P., Budzanowski M., McLaughlin J.P., Waligórski M.P.R., Field Investigations on Radon, Thoron and Penetrating Environmental Radiation in Selected Regions of The Western Balkan Countries, (IRPA 11, Madrid, Spain, 23-28 May 2004), Rep. $6 a 74$. 
